\title{
Refletindo Sobre a Gestão dos Espaços Turísticos: perspectivas para as redes regionais de turismo ${ }^{1}$
}

\author{
Refleting on the Management of Tourist Spaces : prospects for regional \\ tourism networks
}

\author{
Aguinaldo Cesar Fratucci ${ }^{2}$
}

\begin{abstract}
Resumo
Discutir a dimensão espacial do turismo e a sua gestão no contexto das políticas públicas direcionadas para o seu ordenamento e desenvolvimento é o principal foco do presente ensaio. Trata-se de uma reflexão teórica desenvolvida a partir da observação participante do autor nos últimos trinta anos, nos processo de desenvolvimento turístico do estado do Rio de Janeiro e do Brasil. Baseado no entendimento do turismo como fenômeno socioespacial complexo, resultado dos processos de diferentes agentes produtores, propõe o entendimento do espaço turístico a partir da categoria de territórios-redes que tendem a se ampliar para a escala regional. Questionando o descaso das políticas publicas recentes direcionadas para o ordenamento do turismo nacional, sugere a possibilidade da consolidação de redes regionais como novas instâncias de governança para tal função, desde que sejam frutos de processos endógenos, participativos e realmente democráticos que constituam num novo "espaçotempo" favorável às deliberações democráticas.
\end{abstract}

Palavras-chave: turismo; territórios-redes; redes regionais; políticas públicas

\begin{abstract}
To argue the space dimension of the tourism and its management in the context of the public policies directed for its order and development is the main focus of this paper. One is about a developed theoretical reflection from the participant comment of the author in last the thirty years in the process of tourist development of the state of Rio de Janeiro and Brazil. Based in the agreement of the tourism as complex socioespacial phenomenon, result of the processes of different producing agents, considers the agreement of the tourist space from the category of network-territories that tend if to extend for the regional scale. Questioning the indifference of the recent public policies directed for the order of the Brazilian tourism, suggest the possibility of the consolidation of regional nets as new instances of governance for such function, since that they are fruits of endogenous processes, participative and really democratic that constitute in a new "space-time" favorable to the democratic deliberations.
\end{abstract}

Keywords: tourism; network-territory; regional network; public policies

\footnotetext{
${ }^{1}$ Artigo premiado como melhor trabalho do Seminário Internacional de Turismo - SIT 2008, em Curitiba, PR.

2 Doutor em Geografia da Universidade Federal Fluminense - UFF; professor adjunto do Departamento de Turismo da Faculdade de Administração, Ciências Contábeie e Turismo da Universidade Federal Fluminense. E-mail: acfratucci@turismo.uff.br
} 


\section{Introdução}

Os processos de apropriação dos espaços para o turismo trazem implícito um complexo jogo de variáveis originado a partir da lógica de cada um dos seus agentes produtores e das combinações entre aquelas lógicas. Assim, a busca da compreensão e do ordenamento desses espaços deve, necessariamente, incluir as variáveis oriundas da ação dos turistas, dos agentes do mercado, do poder público (nos seus diversos níveis), dos trabalhadores no setor (diretos e indiretos) e da comunidade receptora em geral. Além disso, devem incluir também, as interações estabelecidas entre cada um daqueles agentes e deles com os outros sistemas que formam o meta-sistema onde se inserem.

Cada um daqueles agentes produtores dos espaços do turismo age e reage de forma específica e particular, assumindo posições e papéis específicos e diferenciados, contribuindo para a complexidade e para o dinamismo daqueles espaços. A combinação das ações e interações de todos os agentes, no tempo e no espaço, compõe o jogo dialógico do turismo contemporâneo, que tem sua territorialidade mais facilmente perceptível nas escalas local e regional.

Entretanto, esta complexidade do fenômeno turístico não vem sendo considerada pelas diversas políticas públicas de turismo já implantadas ou em implantação no país. Mesmo aquelas que oferecem um discurso mais democrático sinalizando para uma maior participação de todos os envolvidos nos processos de decisões, pecam por priorizar em suas diretrizes e propostas de ações, os agentes de mercado. Nota-se, até com certa facilidade, que as características específicas dos demais agentes produtores não vêm sendo efetivamente contempladas no bojo das políticas e das ações direcionadas para o incremento e o ordenamento do desenvolvimento turístico brasileiro.

Em outros termos, as políticas públicas direcionadas para o (re) ordenamento dos espaços turistificados deveriam observar e atender as necessidades e demandas de cada um dos seus agentes produtores para estimular um processo de desenvolvimento sustentável e duradouro para os destinos turísticos. Nesse sentido, é necessário um esforço para o entendimento das combinações existentes e possíveis entre as diversas lógicas de apropriação dos espaços pelos agentes produtores do turismo contemporâneo, indicando a emergência de revisão nas escalas de atuação daquelas políticas. As escalas político-administrativas atuais - nacional, estadual e municipal - não são mais suficientes para atender às demandas e incorporar as oportunidades geradas pelo turismo a partir da ação dos seus agentes produtores, individual ou coletivamente. 
Ora, se os territórios apropriados para o turismo não coincidem com aqueles limites, as políticas direcionadas para o seu ordenamento não podem ser definidas e/ou circunscritas por eles. Elas carecem de outra escala de observação e de atuação, que permita a flexibilidade necessária para a apreensão de toda a complexidade do fenômeno. Para nós, a escala que vem se revelando mais adequada para tal tarefa é a regional, abrangendo os territórios de dois ou mais municípios ou mesmo, em alguns casos específicos, de dois ou mais estados da federação.

\section{A Apropriação dos Espaços para o Turismo: territórios-rede e redes de turismo}

O processo de apropriação de trechos do espaço pelos diversos agentes do turismo, também conhecido como turistificação, resulta na produção de territórios descontínuos, sazonais e flexíveis. Cada um dos agentes sociais responsáveis por essa produção - turistas, agentes do mercado, Estado, trabalhadores e população local -, age segundo lógicas de territorialização próprias, que variam em diferentes combinações entre a lógica zonal e a lógica reticular. De acordo com Haesbaert (2004), a lógica zonal está relacionada com o controle de áreas ou limites, enquanto a lógica reticular concentra-se no controle dos fluxos e dos pólos de conexões, portanto, das redes. Enquanto a primeira parte de uma concepção espacial de território como superfície contínua, mais ou menos homogênea e até certo ponto estática, segundo a concepção bidimensional do espaço euclidiano, a lógica reticular incorpora o movimento como ponto importante na constituição dos territórios e das territorialidades (ibidem).

As ações e as práticas de cada um daqueles agentes sociais compõem um complexo feixe de relações que se refletem nos espaços turísticos, dando-lhes uma dimensão espacial marcada pela descontinuidade territorial e pela intensa mobilidade. $\mathrm{Na}$ contemporaneidade a turistificação dos espaços revela-se importante fator de reordenamento dos espaços, a partir da refuncionalização dos seus fixos e da produção de territórios "esgarçados", estruturados em malhas de pontos e linhas, mais ou menos densas. Enquanto a lógica de apropriação dos espaços do turista é essencialmente reticular e marcada pela mobilidade, para o poder público e para a comunidade local ela é fortemente zonal; já para os agentes de mercado e para os trabalhadores do setor ora ela é zonal ora é reticular. A combinação dessas diferentes lógicas dos agentes sociais produtores do turismo, apontam para a constituição de um espaço do 
turismo ora contínuo (zonal) ora entrecortado (reticular), constituindo um território-rede, trazendo assim implicações específicas para as políticas de planejamento.

Os espaços apropriados para o turismo revelam a organização de um território que deve ser visto e analisado "através de uma perspectiva integradora entre as diferentes dimensões sociais" (HAESBAERT, 2004, p. 74) de cada um dos seus agentes. Esta perspectiva integradora, portanto complexa, nos leva a assumir, seguindo as proposições de Haesbaert, o território do turismo e os processos de territorialização dos seus diversos agentes,

(...) como fruto da interação entre relações sociais e controle do/pelo espaço, relações de poder em sentido amplo, ao mesmo tempo de forma mais concreta (dominação) [especialmente pelo Estado e pelos agentes do mercado] e mais simbólica (um tipo de apropriação) [processo mais visível entre os turistas e a população local] (ibidem, p. 235).

A sociedade contemporânea, para alguns, dita pós-moderna, experiencia o "viver em redes", em que os territórios e as territorialidades passam a ser concebidos e caracterizados pelo movimento, pela fluidez e pelas interconexões, portanto, pelas redes. Assim como outras atividades econômicas contemporâneas, o turismo concretiza-se pela ação, pela articulação e pela interconexão dos seus diversos agentes produtores no tempo e no espaço. Isto nos abre a possibilidade de pensarmos o turismo e, em especial a sua dimensão espacial, a partir da perspectiva das redes e dos territórios-rede, descontínuos e sobrepostos.

O conceito de rede, presente em diversas formas de representação do mundo proposta pelo homem desde a Antiguidade, adquiriu uma posição de destaque enquanto recurso de análise de diversas disciplinas das ciências humanas, inclusive da geografia (DIAS, 2007). A ênfase imposta pelo regime de acumulação flexível que caracteriza o atual estágio do capitalismo, nos fluxos de capital, mercadorias e de informações, nos leva a assumir as redes como um recurso metodológico e analítico mais apropriado para a compreensão da organização espacial dos territórios apropriados para o turismo.

Segundo Dias (2007), na atualidade o conceito de rede vem sendo aplicado como forma de organização social, urbana, econômica, política e técnica. Para a autora, a rede técnica é a que mais se destaca sendo "objeto de muitas representações, freqüentemente marcadas por discursos prospectivos, segundo o pressuposto da casualidade linear entre o desenvolvimento técnico e as mudanças sociais e espaciais" (ibidem, p. 12). No entanto, ela nos alerta para o 
fato da articulação das redes com o desenvolvimento técnico acelerado característico do século XX, envolver um debate "fortemente marcado por um viés determinista". Este debate, muitas vezes passional e ideológico, pode nos levar a entender as redes como o "sujeito capaz de criar condições sociais inéditas e de estruturar territórios” (ibidem, p. 13), superestimando o poder de mudanças técnicas.

De acordo com Musso (2003), com o desenvolvimento dos computadores e das redes de teleinformáticas, notadamente a Internet, ocorre uma nova extensão da representação das redes para toda a sociedade, por ele denominada de "tecno-utopia reticular" que articula dois pontos centrais do seu conceito de rede: a antiga narrativa envolvendo corpo e técnica, colocando o corpo, mais especificamente, o cérebro frente a frente com a rede e, a narrativa moderna de Saint-simon, que tem a rede técnica como uma propulsora política de mudanças sociais. (MUSSO, 2003).

Buscando minimizar o predomínio das redes técnicas, Dias (2007), citando Jean-Marc Offner (2000), nos chama a atenção para a necessidade de cuidarmos para não nos redermos ao determinismo tecnológico atual, como ocorreu com Manuel Castells na sua obra Sociedade em Rede (1999). Para tanto, a autora nos orienta a pensar as redes como resultado das ações dos agentes sociais e não como sujeitos daquelas ações. Isto nos leva a tirar o foco das redes técnicas e levá-lo para o conjunto das ações dos agentes sociais que engendram aquelas redes:

Instável no tempo, móvel e inacabada como já apontou Raffestin (1980), a idéia da rede certamente ilumina um aspecto importante da realidade - chama a atenção para a complexidade das interações espaciais, resultantes dos conjuntos de ações desencadeadas em lugares mais ou menos longínquos. Assim, a rede representa um dos recortes espaciais possíveis para compreender a organização do espaço contemporâneo. (DIAS, 2007, p. 23).

Por outro lado, segundo Raffestin (1980), "toda prática espacial, mesmo embrionária, induzida por um sistema de ações ou de comportamento se traduz por uma produção territorial que faz intervir tessitura, nó e rede” (1993, p.150). Os deslocamentos espaçotemporais dos turistas estabelecem um feixe de relações e de interações entre locais, firmas, instituições e indivíduos, que pode ser representado pelo que Raffestin (1980) classifica como um "sistema de malhas, nós e redes", ou pelo que Souza (1995) propõe como sendo um "território descontínuo ou território-rede". Com base no comportamento e nas ações dos diversos agentes produtores do turismo, o espaço turistificado organiza-se a partir de 
pontos/nós (destinos turísticos) articulados e interligados entre si e com outros pontos/nós (centros emissores), estabelecendo tessituras hierarquizadas, que variam de intensidade e de escala, de acordo com o tipo e o modo do turismo estabelecido.

Em outras palavras, podemos afirmar que, sob a ótica do seu processo e da sua organização, o turismo estabelece uma rede composta por destinos turísticos e por centros emissores (nós), localizados em pontos diferentes do espaço que, por suas características funcionais, mantêm entre si certa ligação de comando. Existe, pois, uma organização que mantém um nível de gerenciamento (por extensão, de poder) sobre eles, interligando-os por meio de objetivos comuns. O ponto/nó emissor precisa do ponto/nó receptor (destino turístico) para satisfazer as demandas dos turistas e para informá-los e transportá-los são necessários as “dutos" (materiais e imateriais) que os unem, formando uma rede complexa (FRATUCCI, 2000b).

Fazendo um paralelo com os territórios-rede proposto por Souza, podemos propor que os agentes do turismo produzem "uma rede complexa, unindo nós irmanados pelo pertencimento a um mesmo comando" (1995, p.92). Entretanto, é importante lembrar que nos vazios existentes entre os destinos turísticos, ou mesmo superpostos a eles, existem outras redes e outras territorialidades, com objetivos distintos.

Por outro lado, "cada nó de um território descontinuo é [...] ele mesmo um território", e “cada território descontínuo é, na realidade, uma rede a articular dois ou mais territórios contínuos" (idem, 1995, p.93-4). Se fizermos o caminho oposto pelos níveis escalares de análise, iremos perceber que, dentro do conceito mais tradicional de território, o destino turístico (nó receptor) apresenta-se como o território mais concreto, quase sempre contínuo e relativamente homogêneo, do turismo. O destino turístico, como espaço vivido apresenta-se, portanto, como

o território onde o turismo se realiza e onde há a ocorrência de interações e interrelações temporárias entre o anfitrião e o turista [hoje acrescentamos os agentes de mercado, os trabalhadores e o Estado], aos quais irão permitir um contato direto, sem barreiras (físicas ou simbólicas) entre eles e o reconhecimento da existência do outro, recíproca e simultaneamente. (FRATUCCI, 2000a, p.65)

Importante salientar que a lógica reticular dos territórios-rede não é exclusiva e não deve ser identificada de forma isolada; ela ocorre de forma ao mesmo tempo complementar e concorrente à lógica zonal dos territórios tradicionais. Na realidade, como aponta Haesbaert, a 
lógica zonal do território tradicional (território-zona) "não estabelece em momento algum um relação dicotômica ou dual“ (2004, p. 286) com a lógica reticular dos territórios-rede; “território-zona e território-rede, como espécies de 'tipos ideais', de fato nunca se manifestam de forma completamente distinta" (idem, p.290).

Essa lógica complexa de apropriação do espaço, ora mais zonal ora mais reticular deve ser de alguma maneira, observada e incorporada pelas políticas públicas orientadoras da gestão do desenvolvimento turístico. O descaso para com esse componente do fenômeno turístico tem originado uma série de equívocos responsáveis por muitas perdas de oportunidades e por muitos conflitos e impactos socioculturais e ambientais no país.

A revisão da literatura e das diversas políticas de turismo nos revela certa tradição do uso da região e de diferentes métodos de regionalização nos processos de planejamento dos espaços turistificados. Entretanto, nos parece que a região não seja a categoria mais apropriada para o estudo e para a gestão daqueles espaços, dada as características muito específicas do fenômeno turístico.

Entendemos que a categoria território-rede revela-se mais adequada para avançarmos nos estudos do sistema articulado pelo turismo, de modo complexo, incluindo todos os seus elementos constituintes, suas ações, interações e inter-relações, sejam elas complementares, concorrentes ou antagônicas. A lógica reticular do território-rede nos permite captar a mobilidade e a transformação dos agentes produtores do turismo. Como bem nos coloca Haesbaert (2004, p. 286) a adoção da lógica reticular nos permite captar "a dimensão temporal-móvel do território" e a sua combinação com a lógica zonal nos leva a perceber mais nitidamente o dinamismo, o movimento, as possíveis conexões e a profundidade do espaço apropriado pelo turismo (ibidem). Esse procedimento nos afasta da leitura bidimensional e estática do espaço do turismo, incorporando às nossas observações também a multiplicidade de tempos de cada agente social do turismo.

O território-rede estabelecido pelos agentes produtores do turismo na escala local dos destinos turísticos, resultante da combinação das relações estruturais e funcionais com que cada um deles atua, ultrapassa os limites do território apropriado pelo turista e apresenta especificidades oriundas das próprias características do fenômeno turístico: descontinuidade espacial, sazonalidade e flexibilidade. Tal constatação nos leva a admitir que o espaço apropriado para o turismo é muito mais extenso que aquele apropriado pelo turista, fato que não vem sendo levado em consideração pelos gestores de políticas públicas de turismo. 
As concepções mais clássicas que restringem o espaço turístico aos trechos do espaço onde se concentram os turistas, os atrativos turísticos e os equipamentos turísticos (MIOSSEC, 1976; BOULLÓN, 1990; LOZATO, 1990; OMT, 2003), já não são suficientes para explicar a dimensão espacial do fenômeno turístico atual, que impõe novas relações sociais e funcionais que reorganizam os territórios dos destinos turísticos. Essa reorganização territorial abrange desde as novas redes de comunicações que garantem a acessibilidade dos centros emissores, aos novos usos dado ao solo para atender às funções turísticas, até as relações de concorrência e complementaridade com outros setores e atividades ali existentes, com bem nos coloca o pesquisador espanhol Josep A. Ivars:

La necesidad de ampliar el perímetro del área turística desde el punto de vista del análisis espacial encuentra una clara justificación atendiendo a que los efectos territoriales del turismo no se localizan exclusivamente en el área que concentra los establecimientos de acogida y los principales recursos turísticos, sino que afectan a la estructura territorial de un espacio mas vasto que el percibido comúnmente como turístico. (IVARS, 2003, p.45).

Entretanto, os estudos, observações e ordenamentos dos espaços apropriados pelo turismo tendem a considerar como objeto de sua atenção apenas os trechos do espaço onde o turismo se manifesta concretamente. Ou seja, apenas onde o turista é visível e atuante. Os modelos e teorias disponíveis limitam-se a entender o espaço turístico a partir das ações dos agentes do mercado e dos turistas. Nenhum deles inclui explicitamente nas suas propostas as ações dos demais agentes do fenômeno.

Entretanto, no nosso entendimento, para a atividade turística acontecer, diversas ações e reações de outros agentes sociais, além dos turistas e dos agentes de mercado, são necessárias e acontecem em outras áreas às quais o turista não tem acesso direto ou sequer toma conhecimento da sua existência. O território-rede estabelecido pelos agentes do turismo avança para além dos espaços do turismo ou do turista, ampliando sua influência para uma área periférica, contígua ou não, através de articulações com outras funções urbanas como a residencial e a comercial.

Isto nos leva a considerar a necessidade de ampliação dos limites dos territórios-rede do turismo, com a inclusão das áreas periféricas responsáveis pelo fornecimento de insumos e, principalmente, de mão-de-obra para as empresas produtoras e fornecedoras de serviços turísticos. Desta maneira teríamos o território-rede do turismo composto por uma área 
turística propriamente dita e por uma área circundante - zona periférica - nem sempre claramente definida e, muito raramente, contemplada pelas políticas públicas de gestão do desenvolvimento turístico.

$\mathrm{Na}$ interior da área turística verificamos a presença e a ação de todos os agentes sociais produtores e dos elementos constituintes - atrativos turísticos, equipamentos de recreação e lazer, meios de hospedagem - da atividade turística. Nele as diversas territorialidades dos agentes sociais produtores do turismo se superpõem, entre si e com outras territorialidades de outros agentes e de outros setores, densificando aquele espaço com seus fixos e seus fluxos. Já nas áreas periféricas, composta por áreas urbanas com funções e usos mistos e por áreas residenciais - contiguas ou não - vamos encontrar a presença de outros agentes de mercado indiretamente ligados à cadeia produtiva do setor, da comunidade local e, principalmente, dos trabalhadores diretos e indiretos do setor.

Por outro lado, as ações daqueles mesmos agentes produtores também se voltam para outros destinos turísticos próximos, conforme as suas demandas ou necessidades. O território-rede conformado nos e pelos destinos turísticos na escala local, tende a se complexificar e a se ampliar, aglutinando-se ou sendo absorvido por outros territórios-redes localizados nas suas proximidades, num processo que nos direciona para a escala regional nos estudo do turismo contemporâneo. Além disso, o território-rede estabelecido nos e entre os destinos turísticos mantém também, relações com as áreas de origens dos turistas - áreas emissoras - onde, além deles, encontramos aqueles agentes de mercado que trabalham diretamente para incentivar e direcionar os fluxos de demandas para os destinos turísticos.

$\mathrm{Na}$ medida em que os seus agentes sociais passam a buscar e a constituir articulações com outros destinos turísticos geograficamente próximos, envolvendo outras localidades circunvizinhas, articuladas pelas suas redes de acessibilidade, de comunicações, de transportes e econômicas, ampliam aquele território-rede para a escala regional.

O aumento do número de visitantes provoca a ampliação do número de agentes de mercado e de trabalhadores, tanto no destino turístico em sim como nos seus arredores e nas áreas emissoras. Novos negócios, atividades e serviços vão surgindo para atender as necessidades dos turistas ou para incrementar o consumo de produtos locais como artesanatos, souvenirs e outros produtos "típicos". Essa expansão, tanto do número dos visitantes como dos agentes de mercado, induz a ampliação do espaço turistificado originalmente. O turista é estimulado, seja por motivações próprias ou por estímulos externos, a circular mais pelos arredores do destino 
turístico, buscando outros atrativos desconhecidos ou diferenciados, enquanto os agentes de mercado vão buscando oferecer novos motivos para que eles permaneçam mais tempo aumentem seu consumo.

Exemplo marcante dessa articulação regional de destinos turísticos pode ser verificado na região turística da Costa do Sol do estado do Rio de Janeiro. Até o final da década de 1980, o turista que viajava para Armação dos Búzios, permanecia durante toda a sua estada naquela localidade, raramente saindo de lá para visitar outros pontos da região de entorno. Atualmente, principalmente através da ação dos agentes de mercado com apoio da mídia, os turistas são estimulados a visitar a localidade de Barra de São João e fazer o passeio pelo rio de mesmo nome, assim como ir até Cabo Frio para compras na já famosa rua dos Biquínis, como também a Arraial do Cabo, onde pode encontrar excelentes pontos para mergulho. Observa-se nesse caso, uma clara sobreposição dos territórios-rede de cada uma daqueles destinos turísticos e o surgimento de um território-rede ampliado para a escala regional. Não apenas ocorrem fluxos de turistas de Armação dos Búzios para Cabo Frio, Barra de São João e Arraial de Cabo, como também ocorrem fluxos no sentido inverso, daqueles destinos turísticos para Armação dos Búzios.

Nessas situações, os destinos turísticos localizam-se próximos o suficiente para permitir que os turistas circulem entre eles durante as suas estadas. Desse movimento centrífugo nos deslocamentos dos turistas e nas ações dos outros agentes produtores do turismo, surgem articulações que extrapolam os limites locais e avançam para outros destinos, localizados numa mesma região, ampliando a escala do território-rede do turismo do local para o regional. Dessas articulações entre destinos turísticos, territórios-rede de turismo, podem surgir um complexo de relações e articulações regionais entre seus diversos agentes produtores, constituindo um território-rede regional.

Retomando o referencial do ciclo de vida das destinações (BUTLER, 1980, 2006), podemos apontar que uma das principais estratégias dos agentes de mercado direcionadas para manter seus negócios, tem sido a da ampliação das suas áreas de atuação pela incorporação de novos atrativos turísticos localizados nos arredores do destino turístico onde estão instalados. Pelo lado dos turistas também é possível verificarmos uma tentativa de incluir no período de uma mesma viagem, a visita de vários lugares próximos, o que amplia o espaço apropriado por eles. 
Por outro lado, parte das populações residentes tanto nos destinos turísticos como nos seus arredores, identificam nos turistas e, mais especificamente nos empreendimentos e negócios destinados a atendê-los durantes seus deslocamentos e estada, a oportunidade de emprego ou algum outro tipo de ocupação que lhes garantam renda mais estável. Estimulados pelas facilidades oferecidas pelos sistemas de transportes e de comunicação existentes, se predispõem a realizar deslocamentos diários para chegar aos seus locais de trabalho, contribuindo para o surgimento de fluxos diários de trabalhadores entre os diversos destinos turísticos de uma região e também, com suas áreas periféricas.

A combinação desses diversos fluxos materiais e imateriais estabelecidos entre os diversos destinos turísticos e suas áreas periféricas dá consistência a um território-rede de turismo regional, que se mostra mais denso e intenso durante os períodos de alta estação turística e, mais rarefeito ou mesmo desfeito nos períodos de baixa estação, exigindo dos gestores das políticas públicas uma intervenção mais atenta e dinâmica.

O desenvolvimento dos territórios-redes regionais de turismo, de um modo geral, vem acompanhado do surgimento de redes direcionadas para o melhor aproveitamento dos efeitos multiplicadores da atividade turística - redes econômicas - ou, como forma de resistência das comunidades locais - redes sociais e políticas. Estas redes, que estamos propondo denominar como redes regionais do turismo, os seus limites diretamente relacionados com a oferta de infra-estrutura de acesso e de transportes, fatores limitantes para a principal variável do fenômeno turístico que é o deslocamento dos turistas entre e pelos destinos turísticos.

Voltando aos processos de apropriação do espaço para o turismo, podemos indicar que as características do fenômeno socioespacial e da atividade econômica gerada por ele, podem ser espacialmente visualizadas em territórios-redes na escala local dos destinos que, avançando para a escala regional, compõem territórios-redes regionais, nos quais surgem redes regionais - econômicas, sociais e políticas - de fluxos e relacionamentos baseadas nos elementos, nos agentes e nos efeitos do fenômeno turístico. Tais redes, compostas pela ação e reação de diferentes agentes sociais, podem revelar-se em novas dimensões de governança possíveis para a gestão e o gerenciamento do desenvolvimento ou crescimento do turismo, corroborando o proposto por Dias, para quem

à tradicional combinação de escalas da organização espacial, segundo o modelo da boneca russa - do apartamento ao prédio, do prédio ao quarteirão, do quarteirão ao 
bairro, do bairro à cidade, da cidade à região, da região à nação - somam-se novos arranjos institucionais e espaciais que nos desafiam a redefinir as categorias analíticas que utilizamos para representar o mundo $(2007$, p. 21)

Como propomos, o território-rede regional do turismo estrutura-se e delimita-se pelas redes físicas de acessos, essenciais para os deslocamentos dos diversos agentes produtores do turismo, principalmente dos turistas e dos trabalhadores do setor. É a partir da existência das redes de acessos e do tipo de meios de transportes disponibilizados que os destinos turísticos podem se articular regionalmente.

Os turistas tendem a se deslocar e a circular entre os diversos destinos e locais turísticos em busca de atrativos que lhes propiciem algum tipo de atividade ou experiência peculiar; já os trabalhadores do setor se deslocam pelos diversos pontos da rede regional em busca de novas ou melhores oportunidades de emprego ou ocupação. Atualmente, são cada vez mais comuns os deslocamentos diários dos trabalhadores diretos do setor entre localidades diferentes, na tentativa de melhorar sua renda e sua qualidade de vida. A melhoria das facilidades de acesso e de transportes tem intensificado, não só no âmbito do turismo, tais deslocamentos diários de trabalhadores entre localidades distintas. A expansão e aglomeração dos territórios-rede do turismo estimulam o crescimento desses fluxos diários de trabalhadores entre os destinos turísticos de uma região, assim como também, ampliam o processo de crescimento das suas áreas periféricas pela necessidade de moradia daqueles mesmos trabalhadores.

Os agentes de mercado por sua vez, apesar da aparente fixidez dos seus empreendimentos, ao perceberem as possibilidades de incorporação de novos atrativos aos seus produtos, logo iniciam o estabelecimento de contatos com outros agentes de mercado no intuito de ampliar suas margens de lucro. Esses contatos vão permitir o estabelecimento de redes regionais de negócios, conhecidas como clusters, arranjos ou cadeias produtivas, estruturadas a partir de objetivos econômicos comuns a todos os agentes da atividade turística. Em virtude da sua maior agilidade de ação, os agentes de mercado sempre se antecipam às ações dos demais agentes do turismo, impondo sua lógica de apropriação dos espaços e dos demais recursos. Portanto, a ampliação dos territórios-redes do turismo tem nos agentes de mercado seu indutor primário e mais ativo que, na busca de novas oportunidades de ampliação da sua lucratividade, incorporam novas áreas e atrativos ao seu negócio. Os turistas por sua vez, também induzem a ampliação dos espaços apropriados para o turismo na medida em que 
sempre querem acrescentar algo novo às suas experiências vividas durante seus deslocamentos e permanências fora dos seus locais de residência habitual.

A intensa mobilidade dos agentes sociais do turismo e o crescimento bastante significativo dos agentes de mercado em novos destinos turísticos têm levado ao surgimento de um número bastante elevado de redes de destinos e de relacionamentos entre aqueles agentes sociais. Essas redes físicas, sociais e econômicas, sinalizam para a necessidade de uma mudança nas instâncias de governança responsáveis pela gestão do turismo, uma vez que, as ações de políticas públicas atuais vêm se mostrando ineficazes ou, na melhor das hipóteses, parciais para o ordenamento e a gestão de um setor tão ativo e complexo como é o do turismo.

\section{Perspectivas das Redes Regionais para as Políticas Públicas de Turismo}

Dessa forma, o avanço dos processos de apropriação dos espaços para o turismo para a escala regional nos coloca um novo dilema no âmbito das políticas públicas de turismo: como definir e implementar as diretrizes e as estratégias para a regulação e o ordenamento do seu desenvolvimento? Em outras palavras, em qual escala as políticas públicas devem ser estabelecidas, de modo a garantir a satisfação das necessidades e ansiedades de todos dos agentes sociais produtores envolvidos na produção dinâmica dos espaços do turismo?

Como já colocado anteriormente, diante da complexidade das relações, dos fluxos e das ações dos agentes sociais do turismo, o estudo e a análise dos territórios-redes por eles produzidos ganham mais consistência quando levadas para a escala regional. Michael Hall (2001) nos lembra que a análise concentrada no destino turístico - centrada na escala local - não pode estar descolada das questões relacionadas com "processos que ocorrem em outras meta e micro escalas e relacionamentos com coisas alheias ao destino embora na mesma escala de análise” (2001, p. 137). Isto nos aponta que os destinos não podem ser vistos ou analisados isoladamente, tendo em vista que "estão inseridos em uma complexa rede de relacionamentos socioculturais, econômicos, políticos e ambientais” (ibidem, p. 137).

Para muitos autores, dentre eles Ivars (2003), é necessário diferenciarmos a gestão dos espaços turísticos da gestão dos municípios. Sobre o espaço turístico incidem as decisões de outros agentes sociais além do poder público e, portanto, este último não deve agir sozinho nas decisões de gestão daqueles espaços. A gestão dos municípios está apoiada no marco institucional e legal da organização territorial da Constituição Federal vigente e das 
respectivas leis orgânicas de cada município; já a gestão dos espaços turísticos está vinculada a um conjunto de decisões e de ações de diversos agentes sociais para quem os limites municipais não são ou necessitam ser observados ou respeitados.

Além disso, é essencial e urgente fugir da dicotomia global $\leftrightarrow$ local que predomina nas discussões atuais relativas às formas e escalas de gestão dos processos políticos e de desenvolvimento turístico. Como nos aponta Boaventura de Souza Santos, precisamos reconstruir ou reinventar "um espaço-tempo que favoreça e promova a deliberação democrática" (1999, p.58), onde seja possível caminhar para um processo de regulação e ordenamento dos espaços turistificados que garanta a participação e emancipação plena de todos os agentes sociais neles envolvidos.

Segundo aquele autor, o novo contrato social "não pode confinar-se ao espaço-tempo nacional estatal e deve incluir igualmente os espaços-tempo local, regional e global" (ibidem, p.60). Isto confirma nossa tese de que as políticas públicas de turismo não podem mais ser definidas, implementadas ou impostas apenas a partir das lógicas dos nossos diversos níveis político-administrativos atuais. A complexidade das relações e das interações do fenômeno turístico contemporâneo exige a definição de novos recortes espaciais para a sua regulação. As articulações cada vez mais intensas entre os territórios-rede do turismo apontam para a escala regional onde, redes regionais de relações e inter-relações constituídas pelos e entre seus agentes sociais, criam uma dimensão espaço-tempo complexa de governança do setor.

As políticas são sempre resultados de decisões deliberadas a partir de um conjunto de alternativas propostas para solução de determinados dilemas ou questões de comunidades específicas. Assim, as mesmas incluem as ações, as inações, as decisões e as não decisões dos governos (HALL, 2001). Para tornarem-se públicas devem ser frutos de um amplo processo, aberto, democrático e inclusivo que observe e respeite as práticas sociais existentes nas comunidades onde serão implementadas. Políticas decididas nos ambientes fechados de gabinetes de autoridades do governo não podem e não ganham o status de políticas públicas, limitando-se a serem políticas de governo. Além disso, as políticas públicas devem comportar princípios articulados com uma visão de longo prazo e não apenas constituírem-se de um somatório de programas e projetos arranjados de acordo com os interesses de curto e médio dos governantes.

No âmbito das políticas específicas para o turismo podemos observar que, no Brasil as políticas públicas de turismo somente se tornaram suficientemente coerentes, coordenadas e 
exeqüíveis a partir de 1992, quando o governo federal decidiu assumir, pelo menos do ponto de visto da economia, o caráter estratégico do setor turístico. Entretanto, é preciso destacar o caráter essencialmente governamental dessas políticas, todas, resultado dos projetos políticos de cada grupo de governo e, portanto, direcionadas pelos objetivos e interesses dos seus representantes. Em resumo, antes de serem políticas públicas, são políticas de governo e como tal, ficam mais sujeitas às descontinuidades marcadas por cada ciclo governamental.

A descentralização da gestão do turismo no nosso país, iniciada com a implantação do PNMT no período do governo Fernando Henrique Cardoso (1994-2002), de certa maneira continua se constituindo no eixo central das políticas federais do setor até o momento atual.

A aparente ruptura proposta em 2003, pelo Plano Nacional de Turismo do primeiro ciclo de governo do presidente Lula, representada pela extinção do PNMT e instituição do PRT, apenas confirmou a opção política do governo federal pela descentralização. É importante ressaltar que essa aparente descentralização trás embutida a manutenção do predomínio do poder central. Apesar dos dois programas citados incluírem propostas de estímulo à formação de redes locais e regionais para a gestão participativa do desenvolvimento do setor, ambos continuam baseados na "relação centro-periferia, onde o centro é o elemento ativo ou sujeito da relação" (ENDRES, 2003, p. 235), o que mantém o poder do governo federal sobre todo o processo.

Ambos os programas, PNMT e PRT, têm seu foco estratégico no estímulo ao desenvolvimento turístico a partir da escala local. Enquanto o PNMT buscava agir nos processos de articulação e organização dos diversos setores locais, públicos e privados, envolvidos com a atividade turística, o PRT volta-se mais para a estruturação e formatação de produtos turísticos regionais com qualidade suficiente para competirem nos mercados atuais.

Dito de outra forma, o processo de municipalização do turismo preocupava-se mais com a organização dos diferentes nichos do setor - associações, fóruns, conselhos - enquanto o PRT voltou-se mais para a organização da cadeia produtiva do setor nos espaços das regiões. $\mathrm{O}$ primeiro objetivava mais a organização institucional e administrativa do setor na escala dos municípios; o segundo, coerente com a visão economicista do atual Plano Nacional de Turismo, interessa-se pela organização competitiva do setor na escala regional.

Pessoalmente acreditamos mais na complementaridade e na continuidade daqueles processos que na incompatibilidade entre as suas propostas. As propostas do PNMT, se tivessem tido 
continuidade e sido atualizadas e revistas a partir de avaliações regulares e consistentes, certamente teriam avançados da escala municipal para a regional. Tão logo estruturada e organizada a célula político-administrativa dos municípios, através de seus conselhos e fundos municipais de turismo, a demanda pela necessidade de articulação com seus municípios vizinhos iria vir à tona, pois como já afirmamos o turismo e especialmente o turista, não se preocupa ou respeita os limites, quase sempre imperceptíveis e simbólicos, das fronteiras municipais.

Talvez, a maior falha da descontinuidade política ocorrida entre o PNMT e o PRT esteja no fato dos criadores e executores do segundo terem se demorado a perceber o quanto os resultados do primeiro lhes eram essenciais. A articulação de dois ou mais municípios circunvizinhos em uma região turística só é possível de ocorrer de forma consistente e sustentável, se cada um deles já estiver com sua estrutura local minimamente organizada. Um conselho ou consórcio regional de turismo só terá condições para se consolidar se estiver baseado em conselhos ou fóruns municipais fortes e atuantes.

No atual contexto político-administrativo brasileiro, a articulação regional necessita ser precedida por um processo de articulação municipal, segundo um processo endógeno iniciado na escala local. A não observância desse ponto está diretamente relacionada com a continuidade do poder de decisão do centro, ou seja, a descentralização ocorre gerenciada pelo Estado e não como fruto de processos participativos endógenos consistentes e duradouros. É na escala federal que continua sendo decidido qual região ou qual roteiro será desenvolvido e privilegiado com recursos, o que pode motivar ou desmotivar a ação e a participação dos agentes locais. Em suma, a relação de poder continua sendo do centro para a periferia.

O surgimento e o desenvolvimento de processos participativos endógenos implicam no desenvolvimento de redes locais e regionais de relacionamentos, estruturadas nos pilares básicos da solidariedade e da confiança entre seus participantes (HALL, 2001). Nesse contexto de revisão do papel de cada agente social do turismo nos processos de apropriação dos espaços para o turismo, as redes regionais estabelecidas por eles e entre eles podem propiciar uma nova instância de governança para o desenvolvimento do setor. Entretanto, tais redes regionais só poderão contribuir para a governança do desenvolvimento turístico no caso de serem frutos de processos democráticos, participativos e inclusivos, dentro daquilo que 
Souza Santos (1999) classifica como um "espaço-tempo" favorável à promoção das deliberações democráticas.

A organização, formal ou informal, dessas redes em conselhos, consórcios ou outro tipo qualquer de instância de agentes sociais, pode possibilitar o desenvolvimento de política públicas mais específicas e mais diretamente articuladas com as necessidades e características do setor turístico regional. Esses novos fóruns regionais de discussão e deliberação sobre os processos de desenvolvimento turísticos de determinados trechos do espaço, podem possibilitar uma melhor gestão dos interesses e necessidades de todos os agentes sociais envolvidos e interessados, na medida em que abrangem os limites dos territórios-redes definidos por eles e não ficam restritos aos limites político-administrativos dos municípios. Logicamente que os representantes do poder público municipal, como um dos agentes sociais envolvidos, devem e precisam ter voz e voto nesses fóruns. Sua participação torna-se fundamental como elemento articular e estimulador dos processos de formação de redes políticas, sociais e econômicas.

\section{Referências}

BOULLÓN, Roberto. 1990. Planificación del espacio turístico. México: Trillas.

BUTLER, R.W. 1980. The concept of a tourist area cycle of evolution, implications to management of resources. Canadian Geographer, v.24, n.1, p. 5-12.

2006. The concept $f$ a tourism area cycle of evolution: implications for management of resources. In; BUTLER, R.W. The tourism area life cycle. Applications and modifications. Vol.1. Clevedon-UK: Channel View, p. 3-12.

CASTELLS, Manuel. 1999. A sociedade em rede. Rio de Janeiro: Paz e Terra.

DIAS, L. C. 2007. Os sentidos da rede: notas para discussão. In: DIAS, L. C.; SILVEIRA, L. L. da (org.). Redes, sociedades e territórios. Santa Cruz do sul: EDUNISC, p.11-28.

ENDRES, A. V. 2003. Redes políticas como novo instrumento de condução política do Estado: contextualização frente à complexidade social e possibilidades para o planejamento turístico. Turismo: visão e ação. Itajaí, v.5, n.2, p. 217-238, mai/ago.

FRATUCCI, A. C. 2000a. O ordenamento territorial da atividade turística no Estado do Rio de Janeiro: processos de inserção dos lugares turísticos nas redes do turismo. 2000a. $178 \mathrm{f}$. Dissertação (mestrado em geografia) - Instituto de Geociências, Universidade Federal Fluminense, Niterói-RJ.

2000b. Os lugares turísticos: território do fenômeno turístico. . GEOGRAPHIA, revista da pós-graduação em geografia da UFF. Niterói, ano II, n.4, p. 121-133.

HAESBAERT, R. 2004. O Mito da desterritorialização: do "fim dos territórios" à multiterritorialidade. Rio de Janeiro: Bertrand Brasil.

HALL, C. M. 2001. Planejamento turístico: políticas, processos e relacionamentos. São Paulo: Contexto. 
IVARS, J.A. 2003. Planificación turística de los espacios regionales en España. Madrid: Sintesis.

LOZATO-GIOTART, J.P.1990. Méditerranée et tourisme. Paris: Masson.

MUSSO, P. 2003. Le réseau: de la mytholoie grecque a l'idéologie d'internet. In: MUSSO, P. (org.). Réseaux et société. Paris: Press Universitaires de Rance, p.15-42.

OFFNER, J.M. 2000. Territorial deregulationn' : local authorities at risk from technical networks. International Journal of Urban and Regional Research, v. 24.1, p.165-182, march 2000.

OMT, 2003. Organização Mundial do Turismo. Turismo Internacional: uma perspectiva global. Porto Alegre: Bookman.

RAFFESTIN, C. 1993. Por Uma Geografia do Poder. São Paulo, Ática. (tradução da edição francesa, 1980)

SOUZA, M. J. 1995. O território: sobre espaço e poder, autonomia e desenvolvimento. In:Geografia: conceitos e temas.CASTRO, I. E.; GOMES, P. C. da C. Rio de Janeiro: Bertrand Brasil, p. 77-116

SOUZA SANTOS, B. 1999. Reinventar a democracia: entre o pré-contratualismo e o pósconstratualismo. IN: HELLER, A. Et al. A crise dos paradigmas em ciências sociais e os desafios para o século XXI. Rio de Janeiro: Contraponto, p. 33-75.

Recebido em : 28/07/2008

Aprovado em : 22/09/2008 